\title{
WILD OAT CONTROL AND TOLERANCE OF GRASS SEED CROPS TO FENOXAPROP-P-ETHYL
}

\author{
M.P. ROLSTON and W. ARCHIE \\ AgResearch, P.O. Box 60, Lincoln
}

\begin{abstract}
Fenoxaprop P-ethyl, a wild oat herbicide was applied to five grass species. Perennial ryegrass was tolerant to $37 \mathrm{~g} / \mathrm{ha}$, but there was a trend for a reduction in seed yield at $75 \mathrm{~g} / \mathrm{ha}$. Two Bromus species had good tolerance, but Phalaris aquatica seed yields were reduced by $80 \%$. In a second trial, there was no significant effect on seed yield of perennial and hybrid ryegrass to fenoxaprop applied at $56 \mathrm{~g} / \mathrm{ha}$. However, there was a trend for $75 \mathrm{~g} / \mathrm{h}$ a to reduce seed yield in perennial ryegrass. In a perennial ryegrass seed crop, wild oats were very competitive, reducing seed yields from $2600 \mathrm{~kg} / \mathrm{ha}$ (best herbicide treatment) to $660 \mathrm{~kg} / \mathrm{ha}$ in the untreated control. Excellent wild oat control was achieved with fenoxaprop at rates of $45 \mathrm{~g} / \mathrm{ha}$ in August and $56 \mathrm{~g} / \mathrm{ha}$ in September.

Keywords: fenoxaprop, prairie grass, ryegrass, seed crops, wild oat.
\end{abstract}

\section{INTRODUCTION}

In grass seed production, wild oat (Avena fatua) is a prohibited weed. Wild oat seed contaminated 6.1\% (1989) and 1.2\% (1997) of perennial ryegrass (Lolium perenne) seedlots (Rowarth et al. 1990; National Seed Laboratory, Palmerston North). In addition to seed quality issues, some trials have shown seed yield increases through wild oat control. Seed yield of Ruanui ryegrass was increased by $38 \%$ with the control of wild oats $\left(134 \mathrm{stems} / \mathrm{m}^{2}\right)$ using benzyl-prop ethyl applied early November, and $24 \%$ when applied mid November (Allen et al. 1974). Considerable reduction in seed yield potential may have occurred because of the late application date. In other trials, ryegrass seed yield increases associated with wild oat control have ranged from 1382\% (Barber 1976; Evans et al. 1976; Lee 1975).

Fenoxyprop herbicide is currently registered in New Zealand for use in wheat to control wild oat (Avena fatua) and lesser canary grass (Phalaris minor). Fenoxaprop has been evaluated overseas for use in ryegrass seed crops to control rough-stalked meadow grass (Poa trivallis) and blackgrass (Alopecurus myosuroides) (MuellerWarrant 1990; Budd 1995). In Oregon, fenoxaprop is registered for use on perennial ryegrass, and only four annual ryegrass (Lolium multiflorum) cultivars. Other annual ryegrass cultivars are regarded as being too susceptible to injury. The Oregon label allows for application after the crop has been established for at least a month for autumn sown ryegrass and tall fescue (William et al. 1995).

This paper reports on the evaluation of fenoxaprop, the tolerance of five grass species and the control of wild oat in perennial ryegrass with this herbicide.

\section{Tolerance of five grass species (Trial 1)}

\section{METHOD}

The five forage grass species evaluated in these trials were: perennial ryegrass (Lolium perenne) cv. Grasslands Nui; Italian ryegrass (Lolium multiflorum) cv. Concord; prairie grass (Bromus willdenowii) cv. Grasslands Matua; grazing brome (Bromus stamineous) cv. Grasslands Gala and phalaris (Phalaris aquatica) cv. Grasslands Maru.

The species were sown in late March 1995 at the AgResearch Farm, Boundary Road, Lincoln. Individual plots were 1.35 x $2.5 \mathrm{~m}$, and included nine rows. Blocks consisted of the five species in adjoining strips. Blocks were $40 \mathrm{~m}$ long with three 
replicates within a block. The crops received a total of $150 \mathrm{~kg} \mathrm{~N} / \mathrm{ha}$ as urea and were sprayed with the fungicide tebuconazole (Folicur) after head emergence. FenoxapropP-ethyl (Puma S) was applied in mid September at Zadoks Growth Stage (GS) 4, at 37 and $75 \mathrm{~g} / \mathrm{ha}$ with no oil/surfactant additive, with water at 250 litres/ha at $220 \mathrm{kPa}$. At harvest, a $1.0 \times 1.35$ m quadrat was cut from each plot, dried in a hessian bag, before being threshed, cleaned and the seed weighed.

The data analysis for Trial 1 was carried out on log transformed seed yield. The seed yield results are on the back transformed log numbers that are similar to, but not the same as the arithmetic means. Seed yields have been rounded-off to the nearest 10 $\mathrm{kg}$.

\section{Tolerance of ryegrass cultivars (Trial 2)}

The tolerance of two ryegrass cultivars to fenoxaprop was evaluated at Courtney. The cultivars were Yatsyn (perennial ryegrass Lolium perenne, mid-early flowering cultivar similar to Grasslands Nui), and Grasslands Impact (late flowering hybrid ryegrass Lolium hybridum). Impact flowers three weeks later than Nui and Yatsyn.

The cultivars were sown as two adjacent blocks on the 28 March 1996 at $10 \mathrm{~kg} /$ ha in $15 \mathrm{~cm}$ rows. Plots were $4 \times 4 \mathrm{~m}$ and were replicated 5 times. Diazinon was applied in April for grass grub control. Broadleaf weeds were controlled with bromoxynil + diflufenican (Jaguar 1.5 litres/ha) + ethofumesate $1.0 \mathrm{~kg} / \mathrm{ha}$ applied on 6 May. Plots were heavy rolled on the 27 August. Nitrogen (N) was applied on 24 July (24 kg N/ ha) and 16 October ( $75 \mathrm{~kg} \mathrm{~N} / \mathrm{ha})$. Foliar diseases were controlled with tebuconazole (190 g/ha) applied on three occasions; 13 November, 9 December and 24 December. Irrigation decisions were based on weekly neutron probe readings. Plots were irrigated on 23 October ( $32 \mathrm{~mm}) ; 21$ November $(42 \mathrm{~mm})$ and Impact also on 8 January 1997 (56 mm).

The fenoxaprop was applied on 18 September at 4 rates; $0,38,56$, and $75 \mathrm{~g}$ ai/ha with no oil/surfactant additives, and water volume of 250 litres/ha applied at $220 \mathrm{kPa}$. The crop growth stage at application was Zadoks GS 31 for Yatsyn (1\% of crop at $1^{\text {st }}$ node stage), and GS 30 for Impact. Visual evaluations for phytotoxicity were made on the 18 October, and subsequently in early and late November.

Plots were harvested by cutting $1.0 \mathrm{~m}^{2}$ quadrats from each plot. Samples were dried in hessian sacks for three weeks before being threshed and cleaned. The purity of each seed sample was determined and the seed yield adjusted to $100 \%$ purity.

\section{Wild oat control (Trial 3)}

The trial was established in perennial ryegrass $\mathrm{cv}$. Verdette sown at $7 \mathrm{~kg} / \mathrm{ha}$ on 7 April 1997 on a Wakanui silt loam near Ashburton. Plots were $21 \mathrm{~m}^{2}$. A randomised block design with three replications was used to evaluate 13 herbicide treatments. Fenxaprop was applied at 0, 45, 56 and $90 \mathrm{~g} / \mathrm{ha}$ without an oil additive, on three dates: late winter (27 August), early spring (30 September) and mid spring (17 October). The wild oat were at Zadoks growth stage (GS) 21-25 (first application) to GS 37 at the last application with the largest plants being $500 \mathrm{~mm}$ tall, and three nodes. Nitrogen $(270 \mathrm{~kg} \mathrm{~N} / \mathrm{ha})$ was applied in 6 equal applications. A preventative fungicide programme with three half rate of tebuconazole $(95 \mathrm{~g} / \mathrm{ha})$ was applied from early November (head emergence). The trial was irrigated regularly. Visual assessments of crop damage from the herbicide treatments relative to the untreated control were recorded. After head emergence samples were collected on 11 November using ground level cuts and dissected to determine dry matter (DM) yield and tiller density of the ryegrass and wild oats. Two weeks before harvest a visual assessment of wild oat control was made. At harvest (29 December 1997), a $1.0 \mathrm{~m}^{2}$ quadrat was cut from each plot, and air dried in a hessian bag, before being threshed, cleaned, weighed and seed yield calculated.

\section{Crop tolerance trials}

\section{RESULTS AND DISCUSSION}

The results indicate good crop tolerance for ryegrass and brome species to fenoxaprop, but not for Maru phalaris (Table 1), which was very sensitive to the herbicide. The annual ryegrass cultivar Concord was tolerant to fenoxaprop. 
TABLE 1: Seed yield (kg/ha) of five grass species treated with fenoxaprop.

\begin{tabular}{lccccc}
$\begin{array}{l}\text { Fenoxaprop } \\
\text { (g ai/ha) }\end{array}$ & $\begin{array}{c}\text { Nui } \\
\text { ryegrass }\end{array}$ & $\begin{array}{c}\text { Concord } \\
\text { ryegrass }\end{array}$ & $\begin{array}{c}\text { Matua } \\
\text { prairie } \\
\text { grass }\end{array}$ & $\begin{array}{c}\text { Gala } \\
\text { grazing } \\
\text { brome }\end{array}$ & $\begin{array}{c}\text { Maru } \\
\text { phalaris }\end{array}$ \\
\hline 0 & 1350 & 1940 & 3870 & 1840 & $200 \mathrm{a}^{1}$ \\
37 & 1320 & 1800 & 3690 & 1820 & $40 \mathrm{~b}$ \\
75 & 1110 & 1700 & 4220 & 2100 & $10 \mathrm{~b}$ \\
LSD P<0.05 & $\mathrm{NS}$ & $\mathrm{NS}$ & $\mathrm{NS}$ & $\mathrm{NS}$ & $\mathrm{S}$ \\
\hline
\end{tabular}

${ }^{1}$ means followed by different letters are significantly different, LSD $\mathrm{P}<0.05$.

There was no significant effect of fenoxaprop on the seed yields of Yatsyn and Impact (Table 2), but there was a trend for a small seed yield decline at $75 \mathrm{~g} / \mathrm{ha}$ rate for Yatsyn. At the time of application, Yatsyn had just entered the stem elongation phase (GS 31), compared to Impact which had not started stem elongation. In Trial 1, this same trend for a yield decline at higher rates occurred with Nui perennial ryegrass at $75 \mathrm{~g} /$ ha rate (Table 1 ) when the perennial ryegrass was at a GS 4 at application time.

TABLE 2: Seed yield and relative seed yield (control $=100)$ of ryegrass treated with fenoxaprop.

\begin{tabular}{lcccc}
\hline $\begin{array}{l}\text { Fenoxaprop } \\
\text { (g ai/ha) }\end{array}$ & $\begin{array}{c}\text { Seed yield } \\
\text { (kg/ha) }\end{array}$ & $\begin{array}{c}\text { Relative } \\
\text { Yield }\end{array}$ & $\begin{array}{c}\text { Seed yield } \\
\text { (kg/ha) }\end{array}$ & $\begin{array}{c}\text { Relative } \\
\text { Yield }\end{array}$ \\
\hline 0 & 1810 & 100 & 1230 & 100 \\
37 & 1840 & 102 & 1230 & 100 \\
56 & 1800 & 99 & 1190 & 96 \\
75 & 1670 & 92 & 1240 & 100 \\
LSD $(\mathrm{P}<0.05$ & $\mathrm{NS}$ & $\mathrm{NS}$ & $\mathrm{NS}$ & $\mathrm{NS}$ \\
\hline
\end{tabular}

\section{Wild oat control}

The wild oat infestation was uniformly distributed among all treatments with a density of 30 to 40 plants $/ \mathrm{m}^{2}$ at 30 September. The effectiveness of the various treatments resulted in wild oat control of 50 to $100 \%$. At the first treatment date (27 August), all three rates of fenoxaprop resulted in total wild oat control (Table 3). A crop assessment made 34 days after treatment (DAT) indicated 17-20\% damage at the 45-56 g/ha rate and $43 \%$ crop damage at the highest rate, with the ryegrass being stunted and a paler green colour. However, these injury symptoms had disappeared by 51 DAT.

Following the second application of fenoxaprop, crop injury at 18 DAT was minor at 8 to $13 \%$, with the crop being a paler green colour with reduced growth. Crop injury from the third application was also minor ( 7 to $13 \%$ ) for fenoxaprop treatments.

\section{Seed yield responses}

The timing of fenoxaprop had a large effect on ryegrass seed yield, with a decline in seed yield of 28 and $64 \%$ respectively for September and October application dates compared to August (Table 4). This reduction is probably the result of competition from wild oats in the period from late August onwards. As in the previous trials (Table 1 and 2) seed yield depressions from fenoxaprop applications made at closing (Table 3 ) were not observed in the absence of wild oats. The density of the surviving wild oat panicles following the September ( 1.3 to 2.7 heads $/ \mathrm{m}^{2}$ ) and October applications $(5.3$ to 12.0 heads $/ \mathrm{m}^{2}$ ) would not have been expected to result in enough competition to cause the large reductions in seed yields that occurred. However, the less effective 
treatments still contained a large amount of wild oat as vegetative tillers (Table 3 ), and these may have been competitive. Only the August treatments resulted in a seed lot that was wild oat free (Table 4).

TABLE 3: Drymatter (DM) weight of wild oat seed heads, vegetative tillers, seed head numbers at 11 November and wild oat control on the 12 December.

\begin{tabular}{lcccrr}
\hline $\begin{array}{l}\text { Application } \\
\text { Date }\end{array}$ & $\begin{array}{c}\text { Fenoxaprop } \\
\text { rate } \\
\text { (g ai/ha) }\end{array}$ & $\begin{array}{c}\text { Heads } \\
\left(\mathrm{DM} \mathrm{g} / \mathrm{m}^{2}\right)\end{array}$ & $\begin{array}{c}\text { Vegetative } \\
\text { tillers } \\
\left(\mathrm{DM} \mathrm{g} / \mathrm{m}^{2}\right)\end{array}$ & $\begin{array}{c}\text { Heads } \\
\left(\mathrm{No} / \mathrm{m}^{2}\right)\end{array}$ & $\begin{array}{r}\text { Control \% } \\
(12 \mathrm{Dec} .)\end{array}$ \\
\hline Control & Nil & $325 \mathrm{a}^{1}$ & $93 \mathrm{bc}$ & $113.0 \mathrm{a}$ & 0 \\
August & 45 & $0 \mathrm{c}$ & $0 \mathrm{c}$ & $0 \mathrm{c}$ & 99 \\
& 56 & $0 \mathrm{c}$ & $0 \mathrm{c}$ & $0 \mathrm{c}$ & 100 \\
September & 90 & $0 \mathrm{c}$ & $0 \mathrm{c}$ & $0 \mathrm{c}$ & 99 \\
& 45 & $11 \mathrm{c}$ & $53 \mathrm{c}$ & $2.7 \mathrm{c}$ & 95 \\
September (cut) & 56 & $4 \mathrm{c}$ & $121 \mathrm{bc}$ & $1.3 \mathrm{c}$ & 97 \\
& 90 & $3 \mathrm{c}$ & $91 \mathrm{bc}$ & $1.3 \mathrm{c}$ & 93 \\
October & 56 & $34 \mathrm{bc}$ & $93 \mathrm{bc}$ & $13.3 \mathrm{bc}$ & 93 \\
& 90 & $0 \mathrm{c}$ & $65 \mathrm{c}$ & $0 \mathrm{c}$ & 97 \\
& 45 & $0 \mathrm{c}$ & $24 \mathrm{c}$ & $0 \mathrm{c}$ & 100 \\
& 56 & $24 \mathrm{bc}$ & $219 \mathrm{~b}$ & $5.3 \mathrm{c}$ & 60 \\
& 90 & $28 \mathrm{bc}$ & $212 \mathrm{~b}$ & $12.0 \mathrm{bc}$ & 60 \\
\hline
\end{tabular}

${ }^{1}$ means followed by different letters are significantly different, LSD P $<0.05$.

TABLE 4: Ryegrass seed yield and wild oat contamination of treated with fenoxaprop.

\begin{tabular}{lccc}
\hline $\begin{array}{l}\text { Application } \\
\text { date }\end{array}$ & $\begin{array}{c}\text { Fenoxaprop } \\
\text { rate (g ai/ha) }\end{array}$ & $\begin{array}{c}\text { Seed Yield } \\
(\mathrm{kg} / \mathrm{ha})\end{array}$ & $\begin{array}{c}\text { Wild oats } \\
(\mathrm{seeds} / 10 \mathrm{~g})\end{array}$ \\
\hline Control & 0 & $650 \mathrm{c}^{1}$ & $21.3 \mathrm{a}$ \\
August & 45 & $2620 \mathrm{a}$ & $0.0 \mathrm{c}$ \\
& 56 & $2500 \mathrm{a}$ & $0.0 \mathrm{c}$ \\
September & 90 & $2690 \mathrm{a}$ & $0.0 \mathrm{c}$ \\
& 45 & $2160 \mathrm{a}$ & $12.3 \mathrm{ab}$ \\
September (cut) & 56 & $1800 \mathrm{~b}$ & $5.7 \mathrm{~b}$ \\
& 90 & $2210 \mathrm{a}$ & $1.0 \mathrm{c}$ \\
October & 56 & $2120 \mathrm{a}$ & $4.3 \mathrm{bc}$ \\
& 90 & $2760 \mathrm{a}$ & $0.7 \mathrm{c}$ \\
& 45 & $1790 \mathrm{~b}$ & $0.3 \mathrm{c}$ \\
& 56 & $1700 \mathrm{~b}$ & $5.7 \mathrm{bc}$ \\
& 90 & $1240 \mathrm{bc}$ & $6.3 \mathrm{bc}$ \\
\end{tabular}

${ }^{1}$ means followed by different letters are significantly different, LSD P $<0.05$.

\section{CONCLUSION}

The evaluation of 4 cultivars of three ryegrass species (perennial, hybrid, and Italian ) suggested that there is good tolerance to fenoxaprop applied in the spring at rates of 37 to $56 \mathrm{~g} / \mathrm{ha}$. However, some cultivars show a decline in seed yield of between 8 to $17 \%$ when the $75 \mathrm{~g} / \mathrm{ha}$ rate was applied. Wild oats are very competitive, even if seed head production is prevented. Applications made after August were less effective at controlling wild oats in autumn sown crops. 


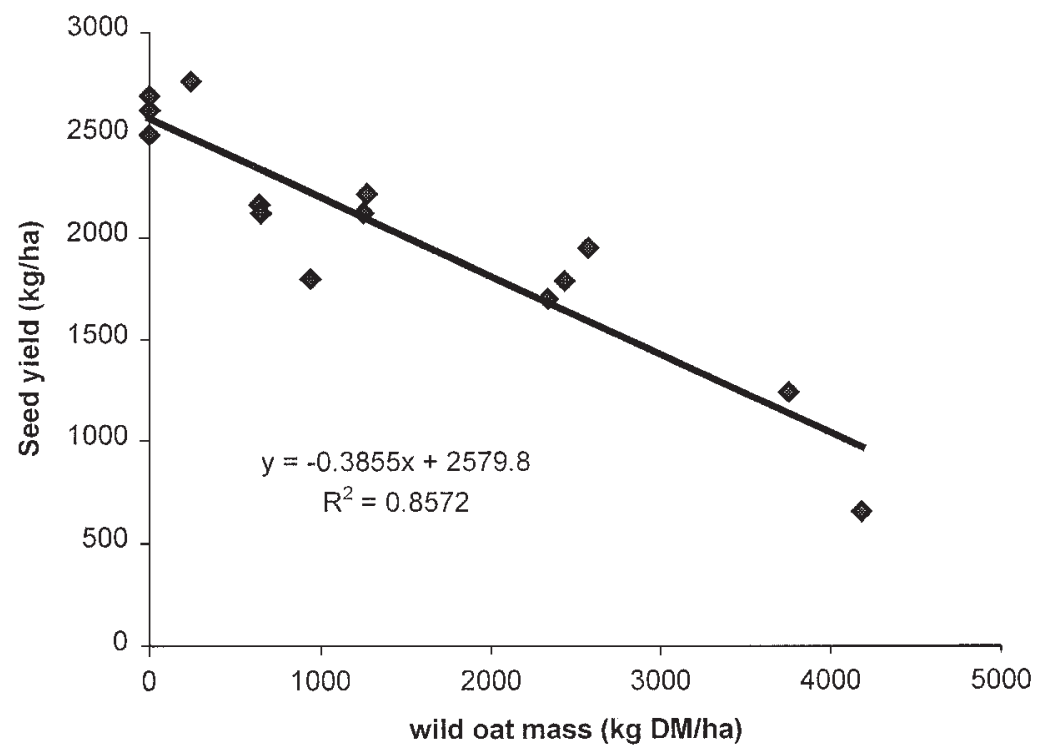

FIGURE 1: Seed yield of perennial ryegrass at different wild oat mass.

\section{ACKNOWLEDGEMENTS}

The author wishes to thank the Foundation for Arable Research (FAR) who funded Trials 1 and 3; NZ Agriseeds Ltd, Courtney. and Technologies for Business Growth (TBG) (Trial 2); and Bruce Turpie, Ashburton for the site used in Trial 3. Data analysis by Lesley Hunt, AgResearch Lincoln.

\section{REFERENCES}

Allen, F.C., Smallridge, T.J., Bourdot and G.W., 1974. Wild oat control in ryegrass for seed production. Proc. $27^{\text {th }}$ N.Z. Weed and Pest Control Conf.: 67-71.

Barber, D.D., 1976. The control of wild oats (Avena spp.) in ryegrass herbage seed crops. Proceedings 1976 British Crop Protection Conference - Weeds: 1047-1051.

Budd, E.G., 1995. The control of blackgrass and volunteer wheat in perennial ryegrass grown for seed. Brighton Crop Protection Conference - Weeds 3: 937-942.

Evans, A.W., John, D.W. and Muncey, D.S., 1976. The effect of a number of chemicals used for wild oat control on seed production of three ryegrass varieties. Proceedings 1976 British Crop Protection Conference - Weeds: 649-655.

Lee, W.O., 1975. Wild oat control in Kentucky bluegrass and perennial ryegrass. Weed Sci. 23: 525-528.

Mueller-Warrant, G.W., 1990. Control of roughstalk meadow grass (Poa trivalis) with fenoxaprop in perennial ryegrass (Lolium perenne) grown for seed. Weed Technol. 4: 250-257.

Rowarth, J., Rolston, M.P. and Johnson, A., 1990. Weed seed occurrence in ryegrass seedlots. Proc. 43rd N.Z. Weed and Pest Control Conf.: 125-129.

William, R.R., Burrill, L.C., Ball, D. and Miller, T.L., 1995. Pacific Northwest Weed Control Handbook. Agricultural Communications, Oregon State University. Pp. 358. 